Article

\title{
Study of the Potential Uses of Hydrochar from Grape Pomace and Walnut Shells Generated from Hydrothermal Carbonization as an Alternative for the Revalorization of Agri-Waste in Chile
}

\author{
René A. Garrido ${ }^{1, *(D)}$, Camila Lagos ${ }^{1}$, Carolina Luna ${ }^{2}$, Jaime Sánchez ${ }^{1}$ and Georgina Díaz ${ }^{2}$ \\ 1 Geographical Engineering Department, Universidad de Santiago de Chile, Santiago 9170022, Chile; \\ camila.lagos.h@usach.cl (C.L.); jaime.sanchez@usach.cl (J.S.) \\ 2 Chemical Engineering Department, Universidad de Santiago de Chile, Santiago 9170022, Chile; \\ carolina.luna@usach.cl (C.L.); georgina.diaz@usach.cl (G.D.) \\ * Correspondence: rene.garridol@usach.cl
}

check for updates

Citation: Garrido, R.A.; Lagos, C.; Luna, C.; Sánchez, J.; Díaz, G. Study of the Potential Uses of Hydrochar from Grape Pomace and Walnut Shells Generated from Hydrothermal Carbonization as an Alternative for the Revalorization of Agri-Waste in Chile. Sustainability 2021, 13, 12600. https://doi.org/10.3390/su132212600

Academic Editor: Munjed A. Maraqa

Received: 30 August 2021

Accepted: 8 November 2021

Published: 15 November 2021

Publisher's Note: MDPI stays neutral with regard to jurisdictional claims in published maps and institutional affiliations.

Copyright: (c) 2021 by the authors. Licensee MDPI, Basel, Switzerland. This article is an open access article distributed under the terms and conditions of the Creative Commons Attribution (CC BY) license (https:/ / creativecommons.org/licenses/by/ $4.0 /)$.

\begin{abstract}
A myriad of resources and efforts have been devoted to assessing the possibilities of using locally sourced biomass to produce energy, reduce $\mathrm{CO}_{2}$ emissions, and, in turn, lower dependance on petroleum. Grape pomace (GP) and walnut shells (WS) are organic waste generated in Chile. Within the last decade, the potential benefits and application of biomass have received significant attention, both in terms of producing functionalized carbon materials, and the various potential applications in the field of energy storage and environmental protection. The proposed research motivation is on the development of carbonous materials through thermal decomposition processes. Few researchers have addressed the idea of developing a multipurpose carbonaceous matrix from hydrochar, and there remains a need for an efficient method to obtain hydrochar specially from grape pomace. Hence, the general objective of this research is to study the potential of grape pomace and walnut shells treated with hydrothermal carbonization (HTC) as an alternative low-cost and efficient carbonous matrix. Proximate and elemental analysis was determined to distinguish the nature of the feedstock along with the hydrochar produced. Yield and reaction severity were also studied to study the impacts of temperature and residence time for both feedstocks. Successful results from the proposed work have broad applications for increasing the sustainability biomass applications, contributing to a positive economic impact.
\end{abstract}

Keywords: grape pomace; walnut shells; hydrothermal carbonization (HTC); thermogravimetric analysis (TGA); hydrochar

\section{Introduction}

The acceleration of climate change in recent decades is the result of the increase in GHGs, produced specifically by the excess use of fossil fuels [1-3]. Chile is a country highly vulnerable to the impacts generated by climate change, hence Chile's proactive stance and commitment to GHG mitigation. One of the most relevant initiatives taken at the national level is the incentive for the use of non-conventional renewable energy (NCRE), which requires that by 2025, 20\% of energy generated comes from these sources [4]. It should be noted that Chile has a varied geographical distribution of these resources, which provides a natural wealth that can be used by NCRE in all its areas [5].

The motivation for this research lies in the exploration for potential uses of the residues produced from grape pomace and walnut shells, two of Chile's important NCRE resources. Through thermochemical conversion and hydrothermal carbonization (HTC), grape pomace and walnut shells become hydrochar, which has several uses, such as soil amendment, energy as pellets, or low-cost adsorbents [6-20]. 
Because of their improved process efficiency, flexibility, faster conversion rate, selectivity, and alternate market for byproducts, thermochemical conversion methods are commercially appealing. The use of lignocellulosic biomass poses many challenges for thermochemical conversion due its inherent high moisture content, low energy content, and inconsistencies between volume and density [21-23]. Hydrothermal conversion is a hybrid method consisting of physical and chemical pretreatment processes performed in aqueous conditions. Successful products of this method include steam explosion, autohydrolysis, liquid hot water, and subcritical water hydrolysis [21].

The repurposing and valorization of grape pomace and walnut shells is directly beneficial to the environment as it reduces feedstock waste. One of the proposed treatment of GP and WS is through what is called as circular bioeconomy (CBE) system; this approach provides promising opportunities through the optimization and repurposing of biomass waste and residual materials [24-26].

Chile's silvoagricultural industry is well-known: cattle, agriculture, and forestry account for roughly $2.9 \%$ of the country's GDP [27]. These sectors generate significant quantities of organic waste from the production and exportation of agricultural and forestry feedstocks [28], most of which is disposed of or sent to landfill [29]. The use of agricultural waste for energy is low; in 2014, eight biogas plants with a total installed capacity of $42 \mathrm{MWe}$ generated $0.4 \%$ of Chile's electricity supply. Two landfills in Santiago, Chile's metropolitan region, create $83 \%$ of the country's biogas, while wastewater treatment plants produce $15 \%$, and manure and organic waste produce 3\% [30]. However, biomass electricity, which is mostly driven by forest inputs, accounts for over $2 \%$ of the country's total installed capacity, with over $500 \mathrm{MWe}$ [31]. Increased use of waste-to-energy products could help to achieve climate change goals, waste reduction, increased energy security, resource efficiency, and reduced air pollution.

Chile's well-known mining makes up 13\% of the nation's GDP [32]. From this industry, great economic benefit is bestowed upon mining communities, but the dangers of this industry are perhaps even greater. The industry is the culprit behind intensive consumption of oil and water, emission of particulate materials, and the generation of polluting effluents with high content of heavy metals and metalloids, all of which are harmful to the population, and require treatment or mitigation strategies [32,33]. It is estimated that globally, there are approximately 3500 active deposits of mining waste, which consist of rock and tailing dumps [32,34]. The increasing demand for essential metals, the decrease in ore grades, and the extraction of complex ore bodies have resulted in larger quantities of loss that require immediate mitigation strategies $[32,35,36]$.

Hydrothermal carbonization (HTC), also known as wet torrefaction or wet pyrolysis, is the decomposition process of organic matter occurring in liquid water, generally in the temperature range of $180-250^{\circ} \mathrm{C}$. The water is at ambient temperature and the pressure in the system is autogenous. This process simulates the natural formation of coal on a laboratory scale $[35,36]$. The HTC process relies on the ability of water to break down ions from other molecules. The hydroxide anions $\left(\mathrm{HO}^{-}\right)$and hydrogen cations $\left(\mathrm{H}^{+}\right)$are separated from the organic molecules, forming water, while said molecules that have been dehydrated combine to form carbon that, later, will be transformed into hydrochar, similar to the way in which carbon undergoes its natural process [36].

Several studies have been conducted related to the waste generated by the wine industry [37-41], along with numerous studies describing the potential of walnut shells [42-48]. More specifically, walnut shell and grape pomace have received great attention regarding HTC processing to study a myriad of variables, such as residence time, temperature, and biomass-water ratio, obtaining results that help to determine the potential use that can be given to the waste, being reused, and preventing it from being considered solely as a waste but as a bioresource [14,16,49-59].

When organic waste is carbonized via hydrothermal carbonization (HTC), it produces interesting carbonaceous powder materials with the required properties to varying degrees, depending on the carbonization parameters and conditions. Carbon characteristics can be 
precisely tuned to the required application, adjusting the temperature or reaction time of the carbonization process. As a result, biomass carbonization is a fascinating and promising process for producing environmentally friendly and bio-based materials for use in energy storage, low-cost adsorbent, and conversion technologies, as well as a powerful tool for converting organic waste streams into value-added products in the bioeconomy [60].

Consequently, this study covers a knowledge deficit by providing an up-to-date characterization of organic waste in Chile, as well as an estimate of the resource potential. Furthermore, this research examines the possibility for hydrochar production from these organic wastes in order to identify hurdles to improve bioresources usage.

\section{Materials and Methods}

Grape pomace was collected from Undurraga vineyard, located in Talagante, Región Metropolitana, Chile. The samples, residual pomace from the vinification process, were processed for storage. Samples were then dried at $60{ }^{\circ} \mathrm{C}$ for $48 \mathrm{~h}$ to remove moisture. Walnut shells were collected from San Alfonso, Cajón del Maipo, Región Metropolitana, Chile. The samples were collected from the 2018 walnut harvest process. Samples were then dried at $105^{\circ} \mathrm{C}$ for $24 \mathrm{~h}$ to remove moisture content. Finally, all samples were carefully stored to prevent decomposition. For analytical studies, all samples were ground and then sifted to obtain samples with particle size less than 50 mesh $(500 \mu \mathrm{m})$.

\subsection{Characterization of Biomass Samples}

Samples were characterized by their proximate analysis, ultimate analysis, and HHV and IR spectra. Proximate analysis was obtained using a thermogravimetric analyzer (TGA) from TA Instrument (Model TGA 5500). For each experiment, sample material was heated to $105{ }^{\circ} \mathrm{C}$, and then to $500{ }^{\circ} \mathrm{C}$ at a heating rate of $10{ }^{\circ} \mathrm{C} \mathrm{min}{ }^{-1}$ under inert atmosphere, to determine the moisture and volatile matter content, respectively. After the weight equilibrium was reached, air was introduced to the reactor, and the temperature was raised to $800^{\circ} \mathrm{C}$ at $10^{\circ} \mathrm{C} \mathrm{min}^{-1}$ to burn off the remaining carbon material in order to determine the amount of fixed carbon and inorganic matters. Proximate analysis was done using the same procedure as described in prior research studies [61-65]. Ultimate analysis was obtained using the Parikh, J. et al. correlation [66], along with HHV [67].

\subsection{HTC Process}

In this study, the hydrothermal process was carried out using three stainless steel $50 \mathrm{~mL}$ HTC reactors. Each HTC reactor contained a polypropylene (PPL) liner that ensured homogeneous conditions inside the reactor. PPL liners were selected based on their capability to withstand temperatures below $280{ }^{\circ} \mathrm{C}$ and pressure up to $3 \mathrm{MPa}$.

In a typical experiment, dried and ground biomass (grape pomace or walnut shells) and distilled water were poured into the liners, based on the biomass/water ratio presented in Table 1. Once the biomass/water mixture was inside the reactor, the reactor was sealed, to later be placed in a muffle furnace at the desired reaction temperature [16,68-70]. The biomass/water ratio along with the selected reaction temperatures are presented in Table 1.

Table 1. Selected HTC reaction parameters.

\begin{tabular}{cccc}
\hline Feedstock & $\begin{array}{c}\text { Biomass: Water } \\
\text { Ratio }\end{array}$ & $\begin{array}{c}\text { HTC Reaction } \\
\text { Temperatures }\end{array}$ & $\begin{array}{c}\text { HTC Reaction } \\
\text { Residence Time (hrs) }\end{array}$ \\
\hline Grape pomace (GP) & \multirow{2}{*}{$5: 1$} & $180^{\circ} \mathrm{C}$ & 1 \\
Walnut shells (WS) & & $200^{\circ} \mathrm{C}$ & 1 \\
& & $200{ }^{\circ} \mathrm{C}$ & 2 \\
\hline
\end{tabular}

Once the HTC process was completed and cooled down, the reactors were opened, and the polypropylene (PPL) liners were removed. Subsequently, the HTC products were filtered. The hydrochar obtained was then dried out and stored. 
Hydrothermal severity is used to evaluate biomass degradation and conversion to understand the effect of residence time and temperature [18]. The hydrothermal process is commonly thought of as a way to prepare lignocellulosic biomass for enzymatic reactions, nutrient recovery, and/or other uses [71]. Based on the equation derived by Overend et al., hydrothermal severity $\left(R_{0}\right)$ is a function of the combined influence of processing temperature and residence time [72]. Where $T$ is temperature in Celsius, $t$ is time in minutes, then $R$ is a mixed severity factor, represented in Equation (2) [73].

$$
\begin{gathered}
R_{0}=t \times \exp \left[\frac{(T-100)}{14.75}\right] \\
R=\log \left(R_{0}\right)-p H
\end{gathered}
$$

\section{Results and Discussion}

\subsection{Biomass Characterization}

From a physicochemical perspective, the results obtained from this study were thoroughly analyzed. The resulting data from the analytical instruments and related correlations were substantiated through a comparison to existing literature.

As previously stated, the initial step in the research was to conduct a compositional analysis to discover the key organic and elemental components. Table 2 shows the composition of the major organics and elemental components of GP and WS, as well as the standard deviation for all the samples examined.

Table 2. Grape pomace (GP) and walnut shell (WS) physicochemical characterization.

\begin{tabular}{ccc}
\hline & Grape Pomace (GP) & Walnut Shells (WS) \\
\hline & Proximate Analysis & \\
\hline Volatile Matter (VM) & $64.62 \% \pm 0.29 \%$ & $71.36 \% \pm 0.98 \%$ \\
Fixed Carbon (FC) & $25.29 \% \pm 0.22 \%$ & $4.97 \% \pm 0.23 \%$ \\
Ash content (AC) & $10.09 \% \pm 0.12 \%$ & $23.67 \% \pm 1.21 \%$ \\
\hline & Elemental Analysis & \\
\hline C (wt. $\%)$ & $45.51 \% \pm 0.06 \%$ & $35.63 \% \pm 0.59 \%$ \\
H (wt. $\%)$ & $5.32 \% \pm 0.01 \%$ & $4.68 \% \pm 0.07 \%$ \\
O (wt. $\%)$ & $38.45 \% \pm 0.08 \%$ & $35.48 \% \pm 0.54 \%$ \\
N (wt. $\%)$ & $0.63 \% \pm 0.001 \%$ & $0.53 \% \pm 0.01 \%$ \\
HHV (MJ $/ \mathrm{kg})$ & $18.94 \% \pm 0.04 \%$ & $12.70 \% \pm 0.24 \%$ \\
\hline
\end{tabular}

\subsection{HTC Yield and Hydrochar Characterization}

The proximate and elemental analysis of hydrochar is required to ensure that it is used efficiently as a fuel [73]. Figure 1 shows the proximate analysis composition of hydrochar products, varying depending on the reaction temperature and residence time for each biomass studied. The increase of residence time significantly reduces the ash content to approximately $2-3 \%$, compared to the $10 \%$ for GP and $23 \%$ for WS. It is worth noting that, overall, hydrochar has a higher fixed carbon content, showing a minimal increase while we increase reaction temperature and residence time.

The subcritical conditions developed during the HTC process boosted high $\mathrm{H}^{+}$concentration, providing an excellent medium for the acid-catalyzed reaction of organic compounds without added acid [73-75]. During the HTC process, the water contained in biomass and supplied to the process was observed to be an outstanding solvent and reaction medium. However, the conditions were somewhat controlled due to the low temperatures. Figure 1 shows how the HTC process affects both feedstocks, considering their inherent differences. As stated in literature, temperatures of $200{ }^{\circ} \mathrm{C}$ showed limited degradation of cellulose, leading to a partial pyrolysis-like process [76], which can be the cause of minimal changes in volatiles and fixed carbon for both studied biomass. 
(A)

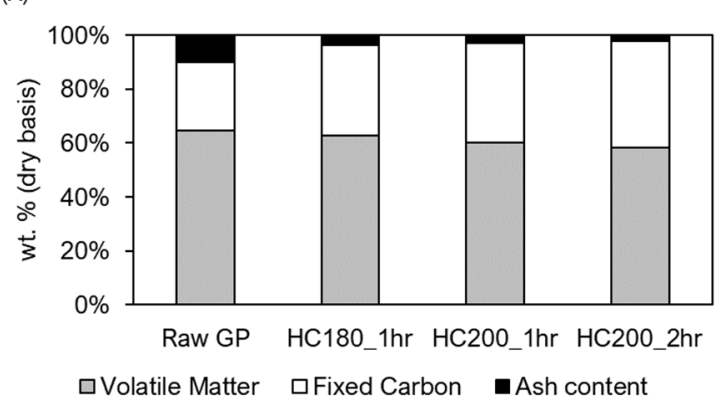

(B)

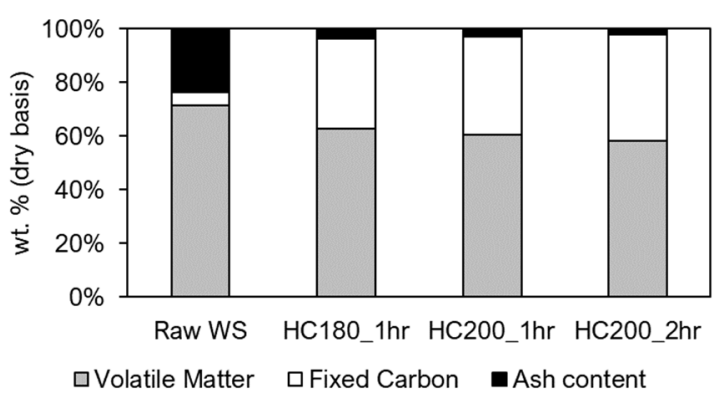

Figure 1. Hydrochar physicochemical characterization. (A) GP hydrochar; (B) WS hydrochar.

HTC modified the elemental make-up of hydrochar marginally, most notably the $\mathrm{H} / \mathrm{C}$ and $\mathrm{O} / \mathrm{C}$ ratios, which may have confirmed the carbonization degree of the hydrochar. Furthermore, the mass loss is highly dependent on the severity of the reaction and the biomass composition [57,73]. Table 3 displays the elemental composition of hydrochar.

Table 3. Hydrochar elemental composition and HHV. (A) Grape pomace hydrochar; (B) walnut shells hydrochar.

\begin{tabular}{cccccccc}
\hline Biomass & $\begin{array}{c}\text { Temperature } \\
\left({ }^{\circ} \mathbf{C}\right)\end{array}$ & $\begin{array}{c}\text { Residence } \\
\text { Time (min) }\end{array}$ & \%C & \%H & \%O & \%N & $\begin{array}{c}\mathbf{H H V} \\
(\mathbf{M J} / \mathbf{k g})\end{array}$ \\
\hline \multirow{2}{*}{ Grape } & 180 & 60 & 49.96 & 5.64 & 40.09 & 0.68 & 21.64 \\
pomace & 200 & 60 & 50.82 & 5.65 & 39.86 & 0.68 & 22.36 \\
& 200 & 120 & 51.70 & 5.67 & 39.78 & 0.68 & 23.04 \\
\hline \multirow{3}{*}{ Walnut shells } & 180 & 60 & 35.47 & 4.65 & 35.18 & 0.53 & 12.7 \\
& 200 & 60 & 36.22 & 4.77 & 36.21 & 0.54 & 22.36 \\
& 200 & 120 & 35.61 & 4.68 & 35.44 & 0.53 & 23.04 \\
\hline
\end{tabular}

Due to its strong hydrophobicity and homogenous qualities, solid residue from the HTC process is considered the primary product of the process, and can be easily separated from the suspension [73,77]. Previous research has shown that the generation of secondary hydrochar from lignocellulosic materials is highly dependent on residence time, as dissolved monomers necessitate substantial polymerization [73]. On the contrary, nondissolved monomers may have an increased dependence on temperature. Controlling the residence time, it was thought, would affect the degree of polymerization of the soluble monomers during HTC, allowing for a pyrolysis-like process. For this study, there was a slight decrease of $\mathrm{O} / \mathrm{C}$ and $\mathrm{H} / \mathrm{C}$ for GP, while WS remained almost constant; these results are in line with the coalification process taking place during the HTC reaction $[78,79]$.

The $\mathrm{H} / \mathrm{C}$ and $\mathrm{O} / \mathrm{C}$ ratios are critical for determining the degree of de-oxygenation and aromatic content during hydrothermal decomposition, as previously indicated.

Residence time is an important component in the production of hydrochar, and it is directly connected to the severity of the reaction. Hydrochar content was high when residence time was low, and decreased as residence time grew, according to the literature [73]. The hydrothermal severity and hydrochar output for this study are shown in Table 4 .

Table 4. Hydrothermal severity and hydrochar yield.

\begin{tabular}{ccccccc}
\hline Biomass & $\begin{array}{c}\text { Temperature } \\
\left({ }^{\circ} \mathbf{C}\right)\end{array}$ & $\begin{array}{c}\text { Residence } \\
\text { Time (min) }\end{array}$ & $\begin{array}{c}\text { Severity } \\
\mathbf{L o g}\left(\mathbf{R}_{\mathbf{0}}\right)\end{array}$ & $\begin{array}{c}\text { Hydrochar } \\
\text { Yield \% }\end{array}$ & H/C Ratio & O/C Ratio \\
\hline \multirow{3}{*}{ Grape pomace } & 180 & 60 & 7.35 & $85.23 \% \pm 7.11 \%$ & 1.354 & 0.602 \\
& 200 & 60 & 18.45 & $88.50 \% \pm 8.09 \%$ & 1.333 & 0.588 \\
Walnut shells & 200 & 120 & 11.13 & $67.22 \% \pm 2.61 \%$ & 1.316 & 0.577 \\
& 180 & 60 & ND & $89.32 \% \pm 9.19 \%$ & 1.573 & 0.744 \\
& 200 & 60 & ND & $93.10 \% \pm 0.25 \%$ & 1.582 & 0.750 \\
\hline
\end{tabular}

ND: not determined. 
Due to the hydrolysis and degradation of hemicellulose and cellulose in biomass, high hydrothermal severity usually results in a low hydrochar yield, as shown in Table 3, and this is consistent with the literature $[73,80]$. Since degradation or inhibitor development can occur when hydrochar is used for additional enzymatic hydrolysis, and the liquid product is utilized to recover nutrients such as xylose and glucose, hydrothermal severity should be regulated [73,80-82]. Typically, for the comparison of raw biomass with hydrochar, the $\mathrm{H} / \mathrm{C}$ and $\mathrm{O} / \mathrm{C}$ ratios are evaluated using a Van Krevelen diagram, but there was no need for this analysis, due to the lack of alterations in the data. The slight changes of $\mathrm{H} / \mathrm{C}$ and $\mathrm{O} / \mathrm{C}$ ratios were presented only in GP. Although lignocellulose-rich hydrochar showed a higher degree of coalification than process-derived hydrochar, the residence time and reaction temperatures may not have changed WS, and this is a strong indication that natural composition plays a key role during HTC [73]. Table 5 provides an overall schematic assessment of comparative studies done with the same feedstocks utilized under similar operative conditions.

Table 5. Overall comparative studies—proximate and elemental analysis. HC (hydrochar).

\begin{tabular}{|c|c|c|c|c|c|c|c|c|c|c|c|c|}
\hline \multirow{2}{*}{\multicolumn{2}{|c|}{ Sample Biomass }} & \multicolumn{2}{|c|}{ HTC } & \multicolumn{3}{|c|}{ Proximate Analysis } & \multicolumn{4}{|c|}{ Elemental Analysis } & \multirow[b]{2}{*}{$\mathrm{pH}^{*}$} & \multirow[b]{2}{*}{ Ref. } \\
\hline & & $\begin{array}{l}\text { Temp. } \\
\left({ }^{\circ} \mathrm{C}\right)\end{array}$ & $\begin{array}{l}\text { Time } \\
\text { (min) }\end{array}$ & $\begin{array}{l}\text { VM } \\
(\%)\end{array}$ & $\begin{array}{l}\text { FC } \\
(\%)\end{array}$ & $\begin{array}{l}\mathrm{AC} \\
(\%)\end{array}$ & $\begin{array}{c}\mathrm{N} \\
(\%)\end{array}$ & $\begin{array}{l}C \\
(\%)\end{array}$ & $\begin{array}{c}\mathrm{H} \\
(\%)\end{array}$ & $\begin{array}{c}\mathrm{O} \\
(\%)\end{array}$ & & \\
\hline \multirow{3}{*}{$\begin{array}{c}\text { Grape } \\
\text { pomace }\end{array}$} & Raw GP & - & - & 67 & 33 & 5.1 & 1.8 & 54.0 & 5.8 & 38.4 & - & \multirow{3}{*}{ [60] } \\
\hline & $\mathrm{HC}$ & 220 & 120 & 53 & 47 & 1.5 & 1.7 & 65.4 & 5.4 & 27.5 & 4.1 & \\
\hline & $\mathrm{HC}$ & 240 & 60 & 50 & 50 & 1.7 & 2 & 67.9 & 5.4 & 24.7 & 4.4 & \\
\hline $\begin{array}{l}\text { Walnut } \\
\text { shells }\end{array}$ & $\begin{array}{l}\text { Raw } \\
\text { WS }\end{array}$ & - & - & - & - & - & 1.5 & 47.6 & 6.0 & 46.3 & - & [81-83] \\
\hline
\end{tabular}

* $\mathrm{pH}$ Process water.

\subsection{Practical Implications of This Study}

Successful results from the development of future work have broad applications for increasing the sustainability biomass applications, contributing to a positive economic impact. The preliminary data obtained can be used to offer a better management of organic wastes, and evaluate the overall techno-economic and environmental benefits gained from the commercialization of the proposed technology. Novel aspect included are: understanding of locally available waste biomass studied; appropriate technology selection for the specific feedstocks; combined functionalization and surface improvement promoting in-situ hydrochar porosity; and the target of chemicals of environmental concern, making this proposal a feasible and sustainable alternative for the utilization of solid organic residue with a higher added value as biomaterials.

\section{Conclusions}

In this study, temperature and reaction time were studied to determine the potential of GP and WS for hydrochar formation. Detailed physicochemical analysis, including proximate and elemental analysis, were examined. The HTC process was studied using two distinctive biomass feedstocks, walnut shells (representing lignocellulosic biomass) and grape pomace (representing processed biomass), which were investigated for a single biomass to water ratio, as well as different temperatures and residence time.

Temperature and residence time controlled the severity of the reaction, as well as the hydrochar yield. However, there is still work to be done in order to increase the de-oxygenation of the biomass to create a carbon-rich hydrochar.

Author Contributions: Conceptualization, R.A.G.; methodology, R.A.G. and G.D.; validation, R.A.G., G.D.; formal analysis, G.D.; investigation, C.L. (Camila Lagos) and C.L. (Carolina Luna); resources, R.A.G.; data curation, C.L. (Camila Lagos), C.L. (Carolina Luna) and J.S.; writing-original draft preparation, R.A.G.; writing-review and editing, J.S.; visualization, G.D.; supervision, R.A.G. and G.D.; project administration, R.A.G.; funding acquisition, R.A.G. All authors have read and agreed to the published version of the manuscript. 
Funding: "This research was funded by UNIVERSIDAD DE SANTIAGO DE CHILE through the DICYT ((Dirección de Investigación Científica y Tecnológica), grant number 021812GL" and "The APC was funded by Proyecto FRAUNHOFER-OC 3134 from UNIVERSIDAD DE SANTIAGO DE CHILE".

Institutional Review Board Statement: Not applicable.

Informed Consent Statement: Not applicable.

Data Availability Statement: Not applicable.

Acknowledgments: Funding of this work was provided by DICYT grant 021812GL from Universidad de Santiago de Chile and the Geographical Engineering department.

Conflicts of Interest: The authors declare no conflict of interest.

\section{References}

1. Carlino, H. El Acuerdo de París y sus Implicaciones para América Latina y el Caribe; 978-1-4244-1530-4; PNUMA. 2016. Available online: https:/ / www.uncclearn.org/wp-content/uploads/library/acuerdo_de_paris_-_implicaciones_en_alc_-_estudio_1.pdf (accessed on 1 August 2021). [CrossRef]

2. Unidas, N. Acuerdo de París; United Nations International Training \& Education Center: Paris, France, 2015.

3. Gómez, M.; Estefanía, V.; Pintó, A. El acuerdo de París: Del Compromiso a la Acción; Oficina Española de Cambio Climático: Madrid, Spain, 2016.

4. Ambiente, M.d.M. Informe del Estado del Medio Ambiente; Ministerio del Medio Ambiente: Santiago, Chile, 2016.

5. República, M.S.G.d.l. Ley 20257; Ley 20257 Introduce Modificaciones a la Ley General de Servicios Eléctricos Respecto de la Generación de Energía Eléctrica con Fuentes de Energías Renovables no Convencionales; Ministerio de Economía: Santiago, Chile, 2008; pp. 1-4.

6. Mendez, A.; Gasco, G.; Ruiz, B.; Fuente, E. Hydrochars from industrial macroalgae “Gelidium Sesquipedale” biomass wastes. Bioresour. Technol. 2019, 275, 386-393. [CrossRef]

7. Shao, Y.C.; Long, Y.Y.; Wang, H.Y.; Liu, D.Y.; Shen, D.S.; Chen, T. Hydrochar derived from green waste by microwave hydrothermal carbonization. Renew. Energy 2019, 135, 1327-1334. [CrossRef]

8. Takaya, C.A.; Parmar, K.R.; Fletcher, L.A.; Ross, A.B. Biomass-Derived Carbonaceous Adsorbents for Trapping Ammonia. Agriculture 2019, 9, 15. [CrossRef]

9. Saqib, N.U.; Sharma, H.B.; Baroutian, S.; Dubey, B.; Sarmah, A.K. Valorisation of food waste via hydrothermal carbonisation and techno-economic feasibility assessment. Sci. Total Environ. 2019, 690, 261-276. [CrossRef]

10. Fang, J.; Zhan, L.; Ok, Y.S.; Gao, B. Minireview of potential applications of hydrochar derived from hydrothermal carbonization of biomass. J. Ind. Eng. Chem. 2018, 57, 15-21. [CrossRef]

11. Ruan, X.X.; Liu, Y.Y.; Wang, G.Q.; Frost, R.L.; Qian, G.R.; Tsang, D.C.W. Transformation of functional groups and environmentally persistent free radicals in hydrothermal carbonisation of lignin. Bioresour. Technol. 2018, 270, 223-229. [CrossRef]

12. Weidemann, E.; Niinipuu, M.; Fick, J.; Jansson, S. Using carbonized low-cost materials for removal of chemicals of environmental concern from water. Environ. Sci. Pollut. Res. 2018, 25, 15793-15801. [CrossRef]

13. Querejeta, N.; Gil, M.V.; Rubiera, F.; Pevida, C. Sustainable coffee-based $\mathrm{CO}_{2}$ adsorbents: Toward a greener production via hydrothermal carbonization. Greenh. Gases Sci. Technol. 2018, 8, 309-323. [CrossRef]

14. Huang, Y.; Huang, Y.; Wang, W.Q.; Zheng, K. Characterization of hydrogen peroxide $\left(\mathrm{H}_{2} \mathrm{O}_{2}\right)$ modified hydrochars from walnut shell for enhanced adsorption performance of methylene blue from aqueous solution. Desalin. Water Treat. 2018, 109, 221-230. [CrossRef]

15. Volpe, M.; Fiori, L. From olive waste to solid biofuel through hydrothermal carbonisation: The role of temperature and solid load on secondary char formation and hydrochar energy properties. J. Anal. Appl. Pyrolysis 2017, 124, 63-72. [CrossRef]

16. Lucian, M.; Fiori, L. Hydrothermal carbonization of waste biomass: Process design, modeling, energy efficiency and cost analysis. Energies 2017, 10, 211. [CrossRef]

17. Pruksakit, W.; Patumsawad, S. Hydrothermal Carbonization (HTC) of Sugarcane Stranded: Effect of Operation Condition to Hydrochar Production. Energy Procedia 2016, 100, 223-226. [CrossRef]

18. Ghanim, B.M.; Pandey, D.S.; Kwapinski, W.; Leahy, J.J. Hydrothermal carbonisation of poultry litter: Effects of treatment temperature and residence time on yields and chemical properties of hydrochars. Bioresour. Technol 2016, 216, 373-380. [CrossRef]

19. Mumme, J.; Titirici, M.M.; Pfeiffer, A.; Luder, U.; Reza, M.T.; Masek, O. Hydrothermal Carbonization of Digestate in the Presence of Zeolite: Process Efficiency and Composite Properties. ACS Sustain. Chem. Eng. 2015, 3, 2967-2974. [CrossRef]

20. Reza, M.T.; Rottler, E.; Herklotz, L.; Wirth, B. Hydrothermal carbonization (HTC) of wheat straw: Influence of feedwater pH prepared by acetic acid and potassium hydroxide. Bioresour Technol. 2015, 182, 336-344. [CrossRef]

21. Sarker, T.R.; Pattnaik, F.; Nanda, S.; Dalai, A.K.; Meda, V.; Naik, S. Hydrothermal pretreatment technologies for lignocellulosic biomass: A review of steam explosion and subcritical water hydrolysis. Chemosphere 2021, 284, 131372. [CrossRef]

22. Sarker, T.R.; Azargohar, R.; Dalai, A.K.; Venkatesh, M. Physicochemical and Fuel Characteristics of Torrefied Agricultural Residues for Sustainable Fuel Production. Energy Fuels 2020, 34, 14169-14181. [CrossRef] 
23. Okolie, J.A.; Nanda, S.; Dalai, A.K.; Kozinski, J.A. Chemistry and Specialty Industrial Applications of Lignocellulosic Biomass. Waste Biomass Valoriz. 2021, 12, 2145-2169. [CrossRef]

24. Atabani, A.E.; Ali, I.; Naqvi, S.R.; Badruddin, I.A.; Aslam, M.; Mahmoud, E.; Almomani, F.; Juchelková, D.; Atelge, M.R.; Khan, T.M.Y. A state-of-the-art review on spent coffee ground (SCG) pyrolysis for future biorefinery. Chemosphere 2021, 286, 131730. [CrossRef]

25. Munawar, M.A.; Khoja, A.H.; Naqvi, S.R.; Mehran, M.T.; Hassan, M.; Liaquat, R.; Dawood, U.F. Challenges and opportunities in biomass ash management and its utilization in novel applications. Renew. Sustain. Energy Rev. 2021, 150, 111451. [CrossRef]

26. Khan, H.A.; Naqvi, S.R.; Mehran, M.T.; Khoja, A.H.; Khan Niazi, M.B.; Juchelková, D.; Atabani, A. A performance evaluation study of nano-biochar as a potential slow-release nano-fertilizer from wheat straw residue for sustainable agriculture. Chemosphere 2021, 285, 131382. [CrossRef]

27. Oficina de Estudios y Políticas Agrarias, ODEPA. Panorama de la Agricultura Chilena; ODEPA: Región Metropolitana, Chile, 2019.

28. Rodríguez-Monroy, C.; Mármol-Acitores, G.; Nilsson-Cifuentes, G. Electricity generation in Chile using non-conventional renewable energy sources-A focus on biomass. Renew. Sustain. Energy Rev. 2018, 81, 937-945. [CrossRef]

29. Ministerio del Medio Ambiente. Nationally Appropriate Mitigation Action, Catalyzing Industrial Organic Waste Management in Chile; Center for Clean Air Policy (CCAP): Washington, DC, USA, 2013.

30. Gaete-Morales, C.; Gallego-Schmid, A.; Stamford, L.; Azapagic, A. Assessing the environmental sustainability of electricity generation in Chile. Sci. Total Environ. 2018, 636, 1155-1170. [CrossRef]

31. Tapia, D. Biomasa en Chile: En Búsqueda de un Mayor Fortalecimiento. Revista Nueva Minería y Energía. Available online: http: //www.nuevamineria.com/revista/biomasa-en-chile-en-busqueda-de-un-mayor-fortalecimiento/ (accessed on 9 November 2021).

32. Wong-Pinto, L.S.; Menzies, A.; Ordonez, J.I. Bionanomining: Biotechnological synthesis of metal nanoparticles from mining waste-opportunity for sustainable management of mining environmental liabilities. Appl. Microbiol. Biotechnol. 2020, 104, 1859-1869. [CrossRef]

33. Adiansyah, J.S.; Rosano, M.; Vink, S.; Keir, G. A framework for a sustainable approach to mine tailings management: Disposal strategies. J. Clean. Prod. 2015, 108, 1050-1062. [CrossRef]

34. Lebre, E.; Corder, G. Integrating Industrial Ecology Thinking into the Management of Mining Waste. Resources 2015, 4, 765-786. [CrossRef]

35. Chryss, A.; Fourie, A.B.; Monch, A.; Nairn, D.; Seddon, K.D. Towards an integrated approach to tailings management. J. S. Afr. Inst. Min. Metall. 2012, 112, 965-969.

36. Jeldres, R.I.; Piceros, E.C.; Wong, L.S.; Leiva, W.H.; Herrera, N.; Toledo, P.G. Dynamic moduli of flocculated kaolinite sediments: Effect of salinity, flocculant dose, and settling time. Colloid Polym. Sci. 2018, 296, 1935-1943. [CrossRef]

37. Yáñez, P.A.; Santiago, S. Caracterización Técnico-Económica de la Implementación de un Sistema Biodinámico en un Viñedo Convencional CV. Carbenet Sauvignon en el Valle de Limarí; Universidad de Chile: Santiago, Chile, 2006.

38. Libra, J.A.; Ro, K.S.; Kammann, C.; Funke, A.; Berge, N.D.; Neubauer, Y.; Titirici, M.M.; Fühner, C.; Bens, O.; Kern, J.; et al Hydrothermal carbonization of biomass residuals: A comparative review of the chemistry, processes and applications of wet and dry pyrolysis. Biofuels 2011, 2, 71-106. [CrossRef]

39. Paul, C.G. Energías Renovables No Convencionales Para uso Domiciliario; Universidad de Chile: Santiago, Chile, 2013 ; p. 85.

40. Ferrer, J.; Mujica, D.; Páez, G.; Fennentaciones, L.D.; Facultad, I.; Universidad, D.I. Producción de un Compostaje a Partir de Desechos de uva Composting from Grape Pomace. In Revista Técnica de la Facultad de Ingeniería; Universidad del Zulia: Zulia, Venezuela, 1993; Volume 16, pp. 191-198.

41. Bordiga, M.; Travaglia, F.; Locatelli, M. Valorisation of grape pomace: An approach that is increasingly reaching its maturity-A review. Int. J. Food Sci. Technol. 2019, 54, 933-942. [CrossRef]

42. Muhlack, R.A.; Potumarthi, R.; Jeffery, D.W. Sustainable wineries through waste valorisation: A review of grape marc utilisation for value-added products. Waste Manag. 2018, 72, 99-118. [CrossRef]

43. Barbosa, F.S.; Scavarda, A.J.; Sellitto, M.A.; Marques, D.I.L. Sustainability in the winemaking industry: An analysis of Southern Brazilian companies based on a literature review. J. Clean. Prod. 2018, 192, 80-87. [CrossRef]

44. Rashtbari, Y.; Afshin, S.; Hamzezadeh, A.; Abazari, M.; Poureshgh, Y.; Fazlzadehdavh, M. Application of powdered activated carbon coated with zinc oxide nanoparticles prepared using a green synthesis in removal of Reactive Blue 19 and Reactive Black-5: Adsorption isotherm and kinetic models. Desalin. Water Treat. 2020, 179, 354-367. [CrossRef]

45. Li, S.Y.; Zhu, X.F.; Li, S.S.; Zhu, X.F. Improved bio-oil distilling effect by adding additives to enhance downstream bio-oil processing and separation. Sep. Purif. Technol. 2020, 247. [CrossRef]

46. Kocaman, S. Removal of methylene blue dye from aqueous solutions by adsorption on levulinic acid-modified natural shells. Int. J. Phytoremediation 2020, 22, 885-895. [CrossRef]

47. Jia, L.X.; Li, C.; Zhang, Y.; Chen, Y.R.; Li, M.Q.; Wu, S.B.; Wu, H.M. Microbial community responses to agricultural biomass addition in aerated constructed wetlands treating low carbon wastewater. J. Environ. Manag. 2020, 270, 110912. [CrossRef]

48. Grzywacz, P.; Czerski, G.; Gazda-Grzywacz, M. Thermogravimetric characteristic of selected biomass gasification. Przem. Chem. 2020, 99, 386-390. [CrossRef]

49. Ahmadinejad, S.O.; Naeeni, S.T.O.; Akbari, Z.; Nazif, S. Investigating the performance of agricultural wastes and their ashes in removing phenol from leachate in a fixed-bed column. Water Sci. Technol. 2020, 81, 2109-2126. [CrossRef] 
50. Yuan, X.H.; Zhu, X.F.; Zhang, L.Q.; Luo, Z.J.; Zhu, X.F. Fundamental Insights into Walnut Shell Bio-Oil Electrochemical Conversion: Reaction Mechanism and Product Properties. Bioenergy Res. 2021, 14, 322-332. [CrossRef]

51. Ricci, F. Producción de Aceite de Pepita de uva, una Herramienta de Creación de Valor Agregado para un Producto Residual; Instituto Tecnologico de Buenos Aires: Buenos Aires, Argentina, 2011; p. 171.

52. Botella, C.; Diaz, A.; de Ory, I.; Webb, C.; Blandino, A. Xylanase and pectinase production by Aspergillus awamori on grape pomace in solid state fermentation. Process. Biochem. 2007, 42, 98-101. [CrossRef]

53. Kambo, H.S.; Dutta, A. Comparative evaluation of torrefaction and hydrothermal carbonization of lignocellulosic biomass for the production of solid biofuel. Energy Convers. Manag. 2015, 105, 746-755. [CrossRef]

54. Benavente, V.; Calabuig, E.; Fullana, A. Upgrading of moist agro-industrial wastes by hydrothermal carbonization. J. Anal. Appl. Pyrolysis 2015, 113, 89-98. [CrossRef]

55. Baratieri, M.; Basso, D.; Patuzzi, F.; Castello, D.; Fiori, L. Kinetic and thermal modeling of hydrothermal carbonization applied to grape marc. Chem. Eng. Trans. 2015, 43, 505-510. [CrossRef]

56. Pala, M.; Kantarli, I.C.; Buyukisik, H.B.; Yanik, J. Hydrothermal carbonization and torrefaction of grape pomace: A comparative evaluation. Bioresour. Technol. 2014, 161, 255-262. [CrossRef]

57. Atchabarova, A.A.; Tokpayev, R.R.; Kabulov, A.T.; Nechipurenko, S.V.; Nurmanova, R.A.; Yefremov, S.A.; Nauryzbayev, M.K. New Electrodes Prepared from Mineral and Plant Raw Materials of Kazakhstan. Eurasian Chem. -Technol. J. 2016, 18, 141-147. [CrossRef]

58. Pecchi, M.; Baratieri, M. Coupling anaerobic digestion with gasification, pyrolysis or hydrothermal carbonization: A review. Renew. Sustain. Energy Rev. 2019, 105, 462-475. [CrossRef]

59. Basso, D.; Weiss-Hortala, E.; Patuzzi, F.; Baratieri, M.; Fiori, L. In Deep Analysis on the Behavior of Grape Marc Constituents during Hydrothermal Carbonization. Energies 2018, 11, 1379. [CrossRef]

60. Purnomo, C.W.; Castello, D.; Fiori, L. Granular activated carbon from grape seeds hydrothermal char. Appl. Sci. $2018,8,331$. [CrossRef]

61. Saha, N.; Volpe, M.; Fiori, L.; Volpe, R.; Messineo, A.; Reza, M.T. Cationic dye adsorption on hydrochars of winery and citrus juice industries residues: Performance, mechanism, and thermodynamics. Energies 2020, 13, 4686. [CrossRef]

62. Hoffmann, V.; Jung, D.; Zimmermann, J.; Rodriguez Correa, C.; Elleuch, A.; Halouani, K.; Kruse, A. Conductive Carbon Materials from the Hydrothermal Carbonization of Vineyard Residues for the Application in Electrochemical Double-Layer Capacitors (EDLCs) and Direct Carbon Fuel Cells (DCFCs). Materials 2019, 12, 1703. [CrossRef] [PubMed]

63. Garrido, R.A.; Reckamp, J.M.; Satrio, J.A. Effects of Pretreatments on Yields, Selectivity and Properties of Products from Pyrolysis of Phragmites australis (Common Reeds). Environments 2017, 4, 96. [CrossRef]

64. Hammer, N.; Starcevich, J.; Garrido, R.; Coe, C.; Satrio, J. Fast pyrolysis of lignocellulosic biomass by 2-step approach for producing fractionated bio-oil products. In Proceedings of the AIChE Annual Meeting, Atlanta, GA, USA, 16-21 November 2014.

65. Zmiewski, A.M.; Hammer, N.L.; Garrido, R.A.; Misera, T.G.; Coe, C.G.; Satrio, J.A. Exploring the Products from Pinewood Pyrolysis in Three Different Reactor Systems. Energy Fuels 2015, 29, 5857-5864. [CrossRef]

66. Hammer, N.L.; Garrido, R.A.; Starcevich, J.; Coe, C.G.; Satrio, J.A. Two-Step Pyrolysis Process for Producing High Quality Bio-oils. Ind. Eng. Chem. Res. 2015, 54, 10629-10637. [CrossRef]

67. Reckamp, J.M.; Garrido, R.A.; Satrio, J.A. Selective pyrolysis of paper mill sludge by using pretreatment processes to enhance the quality of bio-oil and biochar products. Biomass Bioenerg 2014, 71, 235-244. [CrossRef]

68. Parikh, J.; Channiwala, S.A.; Ghosal, G.K. A correlation for calculating elemental composition from proximate analysis of biomass materials. Fuel 2007, 86, 1710-1719. [CrossRef]

69. Parikh, J.; Channiwala, S.A.; Ghosal, G.K. A correlation for calculating HHV from proximate analysis of solid fuels. Fuel 2005, 84, 487-494. [CrossRef]

70. Bejarano, L.; Aguilar, P. Evaluación del biochar e hidrochar como medios para captura de carbono en el suelo. In Trabajo de Grado Para Optar por el Título de Ingeniería Ambiental; Universidad de La Salle: Bogotá, Colombia, 2017; p. 80.

71. Petrovic, J.; Perisic, N.; Maksimovic, J.D.; Maksimovic, V.; Kragovic, M.; Stojanovic, M.; Lausevic, M.; Mihajlovic, M. Hydrothermal conversion of grape pomace: Detailed characterization of obtained hydrochar and liquid phase. J. Anal. Appl. Pyrolysis 2016, 118, 267-277. [CrossRef]

72. Fiori, L.; Basso, D.; Castello, D.; Baratieri, M. Hydrothermal Carbonization of Biomass: Design of a Batch Reactor and Preliminary Experimental Results. Chem. Eng. Trans. 2014, 37, 55-60. [CrossRef]

73. Zhou, Y.; Li, Y.; Wan, C.; Li, D.; Mao, Z. Effect of Hot Water Pretreatment Severity on the Degradation and Enzymatic Hydrolysis of Corn Stover. Trans. ASABE 2010, 53, 1929-1934. [CrossRef]

74. Overend, R.P.; Chornet, E. Fractionation of lignocellulosics by steam-aqueous pretreatments. Philos. Trans. R. Soc. London. Ser. A Math. Phys. Sci. 1987, 321, 523-536.

75. Wang, T.; Zhai, Y.; Zhu, Y.; Li, C.; Zeng, G. A review of the hydrothermal carbonization of biomass waste for hydrochar formation: Process conditions, fundamentals, and physicochemical properties. Renew. Sustain. Energy Rev. 2018, 90, 223-247. [CrossRef]

76. Savage, P.E. Organic Chemical Reactions in Supercritical Water. Chem Rev. 1999, 99, 603-622. [CrossRef]

77. Ruiz, H.A.; Rodriguez-Jasso, R.M.; Fernandes, B.D.; Vicente, A.A.; Teixeira, J.A. Hydrothermal processing, as an alternative for upgrading agriculture residues and marine biomass according to the biorefinery concept: A review. Renew. Sustain. Energ Rev. 2013, 21, 35-51. [CrossRef] 
78. Bobleter, O. Hydrothermal degradation of polymers derived from plants. Prog. Polym. Sci. 1994, 19, 797-841. [CrossRef]

79. Hoekman, S.K.; Broch, A.; Robbins, C.; Zielinska, B.; Felix, L. Hydrothermal carbonization (HTC) of selected woody and herbaceous biomass feedstocks. Biomass Convers. Biorefinery 2012, 3, 113-126. [CrossRef]

80. Zhao, P.T.; Shen, Y.F.; Ge, S.F.; Chen, Z.Q.; Yoshikawa, K. Clean solid biofuel production from high moisture content waste biomass employing hydrothermal treatment. Appl. Energy 2014, 131, 345-367. [CrossRef]

81. Hoekman, S.K.; Broch, A.; Robbins, C. Hydrothermal Carbonization (HTC) of Lignocellulosic Biomass. Energy Fuels 2011, 25, 1802-1810. [CrossRef]

82. Zhang, T.-Y.; Xu, B.; Hu, C.-Y.; Lin, Y.-L.; Lin, L.; Ye, T.; Tian, F.-X. A comparison of iodinated trihalomethane formation from chlorine, chlorine dioxide and potassium permanganate oxidation processes. Water Res. 2015, 68, 394-403. [CrossRef]

83. Naderi, M.; Vesali-Naseh, M. Hydrochar-derived fuels from waste walnut shell through hydrothermal carbonization: Characterization and effect of processing parameters. Biomass Convers. Biorefinery 2019, 11, 1443-1451. [CrossRef] 